\title{
Assessment on Professional Training and Labor Performance of Graduates of the Degree in Sociology
}

\author{
Ana Berónica Palacios Gámaz*, Guadalupe Palacios Gamas, María Guadalupe López Morales, \\ Olga Lidia Lopes Gonzales, Patricia Gutiérrez Casillas
}

Universidad Autónoma de Chiapas

*Corresponding Author: Ana Berónica Palacios Gámaz, Universidad Autónoma de Chiapas

\begin{abstract}
This article presents the results of the research carried out with graduates of the Degree in Sociology, of the Faculty of Social Sciences, of the Autonomous University of Chiapas (UNACH); in particular, the occupational and evaluative orientation of his undergraduate training is analyzed, as well as the level of satisfaction of his professional performance in his current job. The research was carried out through a quantitative methodology, based on the methodological proposal of the National Association of Universities and Institutes of Higher Education (ANUIES). A survey was applied to graduates of the Bachelor of Sociology, who had three years of having completed their undergraduate and specific studies with experience in the labor market. The survey was applied in 2018. The main research findings identified to most graduates currently have a job/employment, and, for the most part, that their bachelor's training did not efficiently prepare them to opt for work in different economic sectors and neither prepared them to link with any particular institution or company; in addition, half the value highly that his undergraduate training prepared him to continue training and to think creatively.
\end{abstract}

Keywords: Graduates, Sociology, professional training, professional performance.

\section{INTRODUCTION}

In the investigation carried out, the objective was to develop the study of graduates of the Degree in Sociology of the Faculty of Social Sciences, of UNACH, through the analysis of professional performance and the degree of satisfaction of their professional training received, which allows generating strategies that provide feedback to the study program and improve the processes of its planning, updating and consolidation.

Contemporary societies increasingly aware, committed and purposeful, require the evaluation and permanent monitoring of the fulfillment of the functions and quality service of their diverse institutions, as is the case of universities, responsible for the training of professionals that allow the advance towards sustainable and sustainable societies in a local-global dynamic, which places higher education institutions in a highly competitive process, facing a demanding, restrictive and precarious labor market, and a society with diverse and complex problems that require of capable and ethical professionals.

In this context, universities must assume as principles, according to the Regional Conference on Higher Education for Latin America and the Caribbean, sponsored by the United Nations Educational, Scientific and Cultural Organization (UNESCO, 2009, cited by Rosales, Rodal, Chumbi and Buñay, 2017), that higher education constitutes a public and social good, is a human right and a duty of the State: "The primary and inalienable value of higher education in the construction of more prosperous, just societies and solidarity as a model of integral and sustainable human development. The integral formation of people, citizens and professionals capable of addressing the multiple challenges and challenges of our society with ethical responsibility and social commitment "(p. 1).

Higher education institutions are in need of the pursuit of educational excellence, the responsibility of permanently innovating, implementing new teaching-learning methods and optimizing their resources, as well as the design of tools that allow systematic monitoring and compliance with quality standards in the educational institution (especially of the accrediting bodies of education programs), for which they 
require strategies for continuous and systematic evaluation of the institution, self-evaluation and feedback

Higher education institutions are currently facing new challenges, among which the social impact generated by professionals in the labor field stands out. Therefore, it is necessary for institutions to create strategies to analyze this process and identify new training demands that respond to society. Thus, graduate studies contribute to improving the quality of education, in order to contribute to the solution of problems.

A relevant aspect in these processes is the institutional feedback provided by graduate studies, which allow students to know the opinions of graduates about the quality of their professional training, the relevance of this in their work performance and suggestions for updating programs Study against the demands of the labor market and the social environment they face (Aldana, Morales, Aldana, Sabogal and Ospina, 2008).

At an international level, the trend of the importance of the evaluation of the activities of the universities is strengthened, which refers to the accountability at the institutional level to both society and government agencies, in which graduate studies constitute an aspect of vital importance (Red Gradua2 and Columbus Association, 2006; cited by Aldana et al, 2008).

Despite the relevance of having the opinions of graduates as fundamental inputs for high quality curricular updating, self-evaluation and accreditation at the higher level, institutions generally lack support from the State, do not have sufficient normative and conceptual support, nor there are rigorous criteria for evaluation, to which the demotivation of graduates to answer the surveys is added (Lopera, 2005).

In this case, the study of graduates of the Degree in Sociology of the Faculty of Social Sciences, of the Autonomous University of Chiapas, in Mexico, aims to generate basic knowledge about the performance of their graduates in their professional fields, approaching the interpretation of its realities, to resignify and resize the educational process, analyze the academic quality of the study program, its relevance, current status and suitability of its pedagogical strategies; elementary inputs for the generation of strategies that provide feedback to the program and improve the planning and consolidation processes.

\section{STUdies of Graduates in MeXico}

Higher education institutions in Latin America in recent years have carried out professional training under a market perspective, related to the growth, development and competitiveness of countries. According to Jiménez (2017), the market is determining the pedagogical orientation of universities (p.3).

In the face of a global social dynamic that faces constant technological innovations, social changes and a tendency towards labor flexibility expressed in labor relations, the use of technology and work organization; International education policy has emphasized the link between universities and market requirements, and demanded an increase in the quality of education offered in higher level institutions, through a flexible curriculum and skills training (Bologna Declaration and World Declaration on Higher Education in the 21st century). In this sense, universities would have an economic and not only social, cultural and pedagogical function, since they have to provide professionals that require the changing labor market, influencing economic growth and social welfare (Ayala, 2009; UAEM, 2009; Guzmán et al, 2008; Escalona and Fernández, 2007; Fresan, 1998).

The link between higher education and the needs of the labor market has been mainly sustained through the Schultz Human Capital Theory (cited by Escalona and Fernández, 2007, p.116), for whom "the worker had in his power a capital, which was the decision to train to perform in a precise activity, to do it with better quality, thus raising their productivity and thus obtaining a better income. That is why the worker owns the human capital and subject to investment since he or the company invests in its preparation, which would pay interest". Hence, it establishes the relationship between human resources training and quality productivity.

Located in contexts of globalization, educational institutions to meet their social and competitive function have sought "quality" educational processes. According to Jiménez (2017), the concept of quality at the higher level is especially related to a political position and market vision: 
In the globalized context in which Latin American universities are framed, the market vision has been decisive in establishing the quality ideal [...] In that sense, the practical consequences resulting from vocational training are often used as an indicator of quality (Jiménez, 2017, p.3).

The quality of higher education institutions considers the development of continuous and systematic evaluation processes that allow them to innovate, discover, design and implement new teachinglearning methods, generating new knowledge, optimizing resources, among other aspects which contribute to the follow-up studies of graduates, which allow to know the professional performance of graduates from their own opinions and also about the quality of the education received, the demands of the labor market and the social environment in which it is located.

The educational quality linked to vocational training and employment has been established in different investigations, such as graduate studies, a relevant tool to enrich educational quality (selfassessment, accreditation through academic peers, etc. has also been considered).

In Mexico, the National Association of Universities and Institutes of Higher Education (ANUIES) (1998) considers that graduate studies allow, mainly, to know the impact that the university education offer has on the labor market; establish the quality of teaching at the university; know the professional location of graduates; analyze the social impact of schools and faculties in the labor market and have information that supports decision making to adapt the university education offer to the existing demand.

Studies of graduates conducted in Mexico, according to Ibarrola (1988, cited by Escalona and Fernández, 2007, p.117), account for the close relationship between schooling-occupation-income and explain income inequalities; as well as questions about it. They also express the high correlation between social conditions of existence and degree of schooling; the general restriction in the employment market and the growth of open unemployment; the bias taken by the distribution of employment towards the sectors of the population with the greatest education; in other aspects.

Among the main contributions of recent research on graduates and carried out in the area of Social Sciences in Mexico (Ayala, 2009; Sandoval, 2009; UAEM, 2009; Guzmán, Febles, Corredera, Flores, Tuyub and Rodríguez, 2008; Escalona and Fernández , 2007), we can mention the generation of knowledge about the characteristics of the employment of professionals, the activities they perform, the knowledge and skills that require them, their performance levels, occupational mobility, salary levels and their impact on expectations professionals and / or academics; also, they allow to know the demands of the employers, to identify the strengths and weaknesses of the curricula, their relevance and efficiency; anticipate the changes to be made in the professional field, design professional profiles according to their field of work, and provide elements that complement the institutional planning based on the opinion of graduates based on their professional life experiences.

In this case, the study of graduates of the Degree in Sociology aims to generate basic knowledge about the performance of their graduates in their professional fields, approaching the interpretation of their realities, to resignify and resize the educational process, analyze the academic quality of the program of study, its relevance, topicality and suitability of its pedagogical strategies; elementary inputs for the generation of strategies that provide feedback to the program and improve the planning and consolidation processes.

\section{RESEARCH METHOD}

The conduct of the research was based on a quantitative methodological strategy. It is an exploratory and descriptive research. A non-experimental research design of the transectional type was developed. The type of sampling was carried out in two stages: first, a simple random probabilistic sampling was performed, complementing with a non-probabilistic technique called Snowball due to the particular characteristics of this study.

The methodological proposal of the ANUIES (1998) was taken as a basis, which was adapted to the context of the object of study with adaptations to the study program (2010) in the year 2018. Based on this, the information of the graduates was obtained through a survey. The questionnaire consisted of open and closed questions, and contemplated ten analysis variables:

$>$ General information and family history. 
$>$ Previous school career.

Trajectory and location in the labor market.

$>$ Satisfaction with your professional performance.

$>$ Requirements in the professional performance of current work.

$>$ Opinion of graduates on the training received.

$>$ Recommendation of graduates to improve the professional training profile.

$>$ Opinion on teachers.

$>$ Opinion on the academic organization and services, and

$>$ Opinion of the graduates about the institution and the degree taken.

In this article we present the results of two variables: the satisfaction of their professional performance, demands in the professional performance of the current work and opinion about the training received.

The subjects participating in this research are graduates of the Bachelor of Sociology, the Faculty of Social Sciences, the Autonomous University of Chiapas, specifically considered graduates who were professionally trained in the 2010 Curriculum, which had a minimum three years after completing his undergraduate studies and preferably with experience in the labor market. In this regard, the first cohort of 2015 was taken as a population of graduates, this generation registered 18 graduates in total (ten women and eight men). For the delimitation of the probabilistic sample, the following formula was used:

$\mathrm{n}=\underline{\mathrm{Np}(1-\mathrm{p})}$

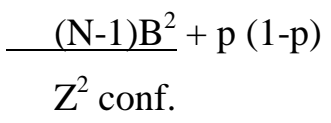

Where: $\mathrm{N}=$ Total population (18), $\mathrm{n}=$ sample size (17), $\mathrm{p}=$ estimate of the proportion $(0.5)$, $\mathrm{z}=$ statistical value that guarantees a predetermined estimate level $(1,645), \mathrm{B}=$ precision level $(0.05)$.

This generation registered 18 graduates in total (ten women and eight men), who are residing in various municipalities in the state of Chiapas, so a sample was created in a chain or network that allowed the graduates to be located by reference from others. It is important to mention that 10 graduates responded to the survey: seven women and three men, equivalent to $56 \%$ of the universe of graduates of the selected generation.

The dispersion of the graduates and the lack of updated data of their current address made it difficult to meet the probabilistic sample, so it was complemented with a non-probabilistic sample and the Snowball technique was used and the stages were as follows : Definition, choice and referencing (Pérez, 2008); thus, only 10 graduates could be located: seven women and three men, which is equivalent to $55.5 \%$ of the universe of graduates (as) of the selected generation, who were surveyed (the application of the survey was conducted in person, by telephone and email, this due to the distance of the communities in which the graduates are located and there was no institutional financing to carry out the field work in the various municipalities of the entity where they currently reside). It should be noted that some graduates refused to answer the survey, despite the persistence with which it was sought and referred to the value of their participation; this demotivation of graduates to answer the questions is expressed in general in the realization of this type of studies (Lópera, 2005); likewise, some graduates could not be found, since there is no updated personal information that allows them to be contacted and their generation partners do not know anything about them.

For the analysis of the variables of this study, it was processed through the statistical package IBM Statistical Package for the Social Sciences (SPSS) version 21.

\section{RESUlts}

The state of Chiapas is located in southeastern Mexico and is characterized by its great social 
inequality, high marginalization and the largest population in poverty in the country.

UNACH, in 2018, served $16.32 \%$ of the total demand for higher level students in the state of Chiapas and constitutes the first option of studies among the institution's higher education institutions and has academic units in 13 of the 15 socioeconomic regions of the entity. It serves an enrollment of 22 thousand 679 students (data from the Administrative Secretariat of UNACH, 2018). Its terminal efficiency in undergraduate is $57.97 \%$, below the national average $(71.5 \%)$.

In the case of the Faculty of Social Sciences of UNACH, this expressed a decrease in enrollment in recent years, in 2017 it had a total of 626 students distributed in the programs taught (Bachelor in Social Anthropology, Economics, History and Sociology) and in 2018 it had 518 students in total (UNACH, 2018).

In what corresponds to the Sociology degree, in the period from 2015 to 2018, the program related to a 29\% decrease in its student population; In the August-December 2018 school year, I had a total of 107 students enrolled (UNACH, 2018).

Since the implementation of the current degree program in Sociology (2010), which consists of eight semesters, as of the second semester of 2018, 333 accepted students enrolled in the Program, of which 136 students graduated, equivalent to $41 \%$, from which derives a global dropout rate of 59\% (Faculty of Social Sciences, Department of School Services, 2018).

Of the total number of graduates of these generations (2014-2017), 49\% have been titled: $85 \%$ through thesis, $9 \%$ through the Seminar, $2 \%$ for postgraduate credits and $4 \%$ graduated by Academic merits (Faculty of Social Sciences, Degree Area, 2018).

The teaching staff of the Bachelor of Sociology program, in August 2018, had 29 teachers: 10 fulltime (35\%), 7 part-time (24\%) and 12 subject (41\%) (Faculty of Science Social, Academic Secretary, 2018).

\subsection{General Data of Graduates and Family History}

As for the sex of the graduates (as) surveyed, according to the information obtained $70 \%$ are women and $30 \%$ men. The maximum age of the graduates is 31 years, the minimum is 23 years old and the average age is 25 years.

Regarding the place of origin of the graduates, according to the information provided, it can be mentioned that the total comes from different municipalities in the state of Chiapas such as: Ocosingo, Unión Juárez, Palenque, Venustiano Carranza, VillaCorzo, Tenejapa, Pijijiapan, Salto de Agua, Bella Vista and San Cristóbal de Las Casas.

Regarding the marital status of the graduates, $70 \%$ declared being single, $10 \%$ are married, $10 \%$ are divorced and $10 \%$ declared another unspecified situation.

According to the data obtained, half of the graduates indicated that they speak only Spanish, while another half are speakers of the indigenous language such as Chol, Tsotsil and Tseltal, in addition to Spanish.

The information provided by the graduates, realizes that in $30 \%$ their parents or head of family have maximum incomplete primary studies; in another 30\% they have incomplete high school studies; in $20 \%$ they have completed high school studies, in $10 \%$ they have incomplete degree studies and in $10 \%$ of graduates their parents or head of family have full degree studies.

Regarding the occupation of the father or head of the household of the surveyed graduates, the information obtained shows that $20 \%$ is a professional employee, $20 \%$ is self-employed, $10 \%$ is an annual worker unqualified, $20 \%$ are ejidatario, $20 \%$ are agricultural laborers and $10 \%$ are retired pensioners.

According to the data obtained, $30 \%$ of graduates mentioned that only one family member contributes to family income, $40 \%$ responded that two family members and $30 \%$ responded that three family members contribute to family income.

As for the income received by the families of the surveyed graduates, $40 \%$ of the families have income of 3 thousand pesos per month and $10 \%$ of the families have income between 1 thousand pesos, 4 thousand, 8 thousand, 10 thousand and 14 thousand pesos, respectively. 
Regarding the financial support that graduates of the Degree in Sociology received during their higher level studies, most of them, $80 \%$, indicated that they received financial support from their parents; $10 \%$ of their sentimental partner and $10 \%$ of the graduates kept up with the income obtained from their work.

\subsubsection{Choice of Institution and Career}

According to the information provided by the graduates surveyed, $50 \%$ said that UNACH was their first option as an educational institution to develop their professional studies, and the other $50 \%$ said it was not their first option.

Also, for $50 \%$ of graduates, the degree in Sociology was their first option; while for the other $50 \%$ it was not his first option, of which $20 \%$ declared that his first option was the career of Social Anthropology, 10\% Economics, 10\% Agricultural Engineer and 10\% responded that the Pedagogy career had been his first choice.

\subsection{Assessment of Professional Performance}

Among the main findings obtained in the study of graduates that was carried out (2018), currently the majority $(70 \%)$ of graduates surveyed have a job and a third is unemployed.

As for the company or institution where graduates who currently have employment are working, it was obtained that: $42 \%$ work in private companies such as financial, stationery and others; $29 \%$ work in public institutions and $29 \%$ work in their own businesses.

The type of recruitment in current employment of graduates, according to the data obtained: $57 \%$ have an indefinite employment contract, $29 \%$ have a fixed-term contract and $14 \%$ did not answer the question.

In relation to the current work coincidence with their undergraduate studies, $14 \%$ of graduates stated that their employment has no coincidence with the degree taken, $43 \%$ said they have medium coincidence, $43 \%$ responded that they have total coincidence.

Of the graduates who have current work, $43 \%$ obtained it at the express invitation of an institution or company, $29 \%$ per job bank, $14 \%$ mentioned that they joined the family business and $14 \%$ did not answer the question.

The economic income received by graduates in their current employment, according to the data obtained, $29 \%$ earn 6 thousand pesos a month; 14\% receive 2 thousand pesos per month, 4 thousand pesos per month, 7 thousand pesos per month, 10 thousand pesos per month and 11 thousand pesos per month, respectively.

As for the time that graduates have lasted in the work they are currently doing, $14 \%$ responded that two months, $29 \%$ three months, $14 \%$ eight months and $29 \%$ mentioned that they have been in their work for twelve months. He did not answer $14 \%$.

Regarding the assessment of graduates on their professional satisfaction in the current work they perform, the following stand out:

- The majority of graduates positively value their satisfaction of putting into practice the knowledge of the degree, as well as the realization of their own ideas in the current work, the teamwork they develop and the possibility of coordinating it;

- Feel professionally recognized;

- Are valued with the ability to respond to work problems;

- are considered satisfied with the content of the work, the work environment, the salary obtained, the hierarchical position reached at work, the possibility of responding to problems of social relevance and the possibility of doing something of benefit to society.

According to the data obtained, regarding the main requirements that graduates have in current professional performance, we can point out the following:

- Most of the graduates who work have a very moderate demand for decision-making, to find solutions to problems, management skills/coordination in the professional performance of their current job. 
- Most of the graduates who work have a moderate to low demand in their professional performance of general knowledge of the discipline, as well as specialized knowledge, skills for handling computer packages, logical and analytical reasoning, skills for public relations and for communication, punctuality and formality, assume responsibilities and creativity.

- Half of the graduates who work have a very moderate demand in the search for relevant and upto-date information in the work they are currently doing, as well as a requirement to work in teams and willingness to learn constantly.

- Just over a third of current graduates have a very moderate demand for risk management in their workplace.

- Most of the graduates who work have little or no demand for knowledge of foreign languages in their position.

Regarding the assessment of graduates on the professional training received, the following can be mentioned:

- Only one fifth of graduates highly valued that their bachelor's training prepared him to opt for jobs in different economic sectors.

- Only one tenth of the graduates highly valued that their undergraduate training prepared them to link with a particular institution / company.

- Half of graduates highly valued that his bachelor's training prepared him to continue training and to think creatively.

With regard to the evaluation of the curriculum of the degree in Sociology that graduates studied, the following stand out:

- Most highly valued the emphasis on theoretical, methodological teaching.

- Half highly valued the emphasis it has on field practices and workshops.

- The majority valued the emphasis on teaching mathematics and statistics from medium to small.

Regarding the evaluation of the graduates on what the curriculum of the Bachelor of Sociology provided them, the following stands out:

- More than one third negatively assessed the general knowledge of a scientific and/or humanistic nature that it provided.

- More than one third positively assessed that it provided him with extensive and up-to-date knowledge of the main theoretical approaches of the discipline; oral, written and / or graphic communication skills; analytical and logical capacity; technical knowledge of the discipline.

- Half valued positively that provided him with the ability to apply knowledge, ability to identify and solve problems.

- The majority valued positively that it provided him with information search skills.

- Also, regarding the evaluation of graduates on the social training granted by their studies in the Degree in Sociology, the following stand out:

- The majority valued positively that encouraged him to be more informed.

- The minority valued positively that prompted it to be more participatory in matters of public interest; it motivated him to generate charitable initiatives for the community.

\section{CONClusions}

The study of graduates of the degree in Sociology, of the Faculty of Social Sciences, of UNACH, is framed in the need to comply with quality standards and relevance of the higher level educational program that we offer, as a strategy of continuous and systematic evaluation that allows the updating of the curricula and the innovation of new teaching-learning methods, through the opinion of the graduates on the quality of their professional training, the relevance of this in their work performance 
and suggestions for the updating of the study programs against the demands of the labor market and the social environment they face.

Derived from the study carried out, it can be considered that, in general terms, the graduates feel satisfied with their professional performance carried out in the current work they develop; However, the majority negatively valued their professional training in terms of quality to grant them the ability to opt for jobs in different economic sectors and to link them with the public and private sectors.

Although the competences that developed with greater emphasis on their professional training are specialized knowledge of the discipline (theoretical, methodological and technical), analytical and logical ability, as well as skills for oral, written and / or graphic communication; the labor field emphatically requires them to develop skills for decision making, problem solving, and management / coordination.

The data obtained show the need to improve the university education of the students of the program, which implies the continuous updating and training of their teachers, as well as the strengthening of the relevance of the curriculum, on which graduates suggest the update and extension of the theoretical, methodological, technical, professional practices, mathematics and statistics contents.

\section{REFERENCES}

[1] Rosales Jaramillo, Guido L., Rodal Genovez, Andrea Y., Chumbi Toledo, Viviana T. y Buñay Andrade, Román M. (2017). Estudio histórico del seguimiento a graduados en la carrera de Psicología de la Universidad de Cuenca, Ecuador. Revista Cubana de Educación Superior, 36(2), 126-141. Recuperado en 20 de junio de 2018, de http://scielo.sld.cu/scielo.php?script=sci_arttext\&pid=S0257-4314201700020001 $2 \& \operatorname{lng}=$ es\&tlng=es.

[2] Aldana de Becerra, G. M.; Morales González, F. A.; Aldana Reyes, J. E.; Sabogal Camargo, F. J. y Ospina Alfonso, A. R. (2008). Seguimiento a egresados. Su importancia para las instituciones de educación superior. Revista Teoría y Praxis Investigativa, Vol. 3, No.2, septiembre-diciembre, pp.61-65.

[3] Lopera, C. M. (2005). Los estudios sobre seguimiento a egresados en los procesos de mejoramiento continuo. La actividad universitaria. Seminario para Funcionarios Universitarios y Gubernamentales sobre Seguimiento de Egresados: Monterrey México). En: www. gradua2.org.mx/docs/monterrey/Ponencia_U_ Catolica_de_Col_GRADUA2_Mexico.doc.

[4] Jiménez Moreno, J. A. (2017). La Evaluación de los Egresados de Formación Profesional en México: Reflejo de la Implementación de la Política de Competitividad en la Educación Superior. Education Policy Analysis Archives/Archivos Analíticos de Políticas Educativas, núm. 25, 1-18.

[5] Ayala Perdomo, J. (2009). Seguimiento laboral de egresados 2008. Licenciatura en Comunicación de la Facultad de Ciencias Políticas y Sociales de la UAEM. Espacios Públicos, 12 (26), 315-328.

[6] Universidad Autónoma del Estado de México (UAEM) (2009). Seguimiento laboral de egresados 2008. Coordinación de Licenciatura en Sociología, Facultad de Ciencias Políticas y Sociales de la UAEM. Revista Espacios Públicos [en línea] 2009, 12 (Diciembre-Sin mes). Disponible en:<http://www.redalyc. org/articulo.oa?id=67612145018>

[7] Guzmán Silva, S.; Febles Álvarez-Icaza, M.; Corredera Marmolejo, A.; Flores Machado, P.; Tuyub España, A. y Rodríguez Reynaga, P. (2008). Estudio de seguimiento de egresados: recomendaciones para su desarrollo. Innovación Educativa, 8 (42), 19-31.

[8] Escalona Ríos, L. y Fernández Cruz, E. (2007). Los estudios de egresados del área bibliotecológica : de la teoría a la práctica. Revista Interamericana de Bibliotecología, Jul.- Dic. 2007, vol. 30, no. 2, 113-135

[9] Fresán Orozco, M. (1998). Los estudios de egresados. Una estrategia para el autoconocimiento y la mejora de las Instituciones de Educación Superior. En Esquema básico para estudios de egresados en educación superior, ANUIES, México.

[10] Asociación Nacional de Universidades e Instituciones de Educación Superior (ANUIES) (1998). Esquema básico para estudios de egresados en educación superior. México.

[11] Pérez Tejeda, H. E. (2008). Estadística para las Ciencias Sociales del Comportamiento y de la Salud. CENGEAGE Learning.3ra. Edición. México, D.F .Páginas 842.Disponible en https://www.uv.mx/rmipe/ files/2015/09/Estadistica-para-las-ciencias-sociales-del-comportamiento-y-de-la-salud.pdf

[12] Sandoval Rubio, M. (2009). Seguimiento laboral de egresados 2008. Licenciatura en Ciencias Políticas y Administración Pública de la Facultad de Ciencias Políticas y Sociales de la UAEM. Espacios Públicos, 12 (26), 292-301.

[13] Universidad Autónoma de Chiapas (UNACH) (2018). Informe de matrículas. Sistema Institucional de Administración Escolar. Recuperado de: http://siae.unach.mx/estadisticas/ 
AUTHORS' BIOGRAPHY

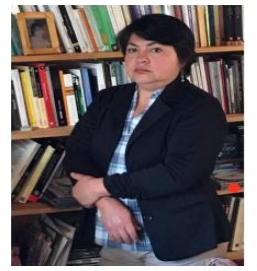

Ana Berónica Palacios Gámaz, Doctor in Scientific-Social Studies, by the Technological Institute of Higher Studies of the West (ITESO). Master in Regional Studies from the Autonomous University of Chiapas. Teacher-Researcher of the Faculty of Social Sciences of the Autonomous University of Chiapas, Mexico. Member of the National System of Researchers of National Council of Science and Technology of Mexico. Honorary Researcher of the State System of Researchers of Institute of Science, Technology and Innovation of the state of Chiapas. Research line: culture, communication, violence and youth.

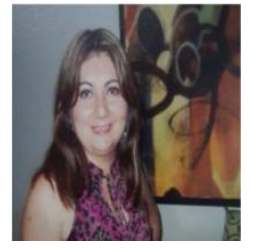

Guadalupe Palacios Gamas, Degree in Psychology from the University of Sciences and Arts of Chiapas. Head of the Gender and Inclusion Department of the Autonomous University of Chiapas. Research lines: gender violence, discrimination, exclusión and youth.

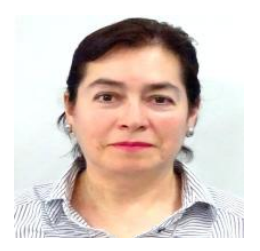

María Guadalupe López Morales. Doctor in Human Rights, from the Autonomous University of Chiapas, Mexico. Master in Procuration and Justice Delivery, from the Autonomous University of Chiapas. Teacher Research of the Faculty of Law of the Autonomous University of Chiapas. Research line: Human Rights, Family Law and Gender.

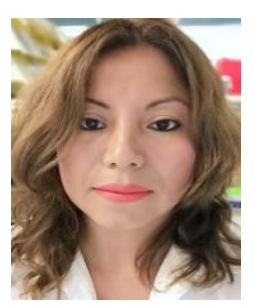

Olga Lidia Lopes Gonzales. Sociologist from the Autonomous University of Chiapas (UNACH) and Master of Science in the Health and Development Line from El Colegio de la Frontera Sur. Professor at the Faculty of Social Sciences (UNACH) and Coordinator of the Committee of Ethics and Health Research of the Hospital de Las Culturas in San Cristóbal de Las Casas, Chiapas, Mexico. Research lines: health in children in contexts of vulnerability, migration and health, sociodemography and gender violence.

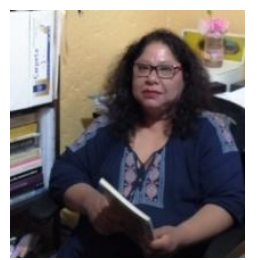

Patricia Gutiérrez Casillas. Doctor in Education from the Institute of Higher Studies of Chiapas. Master in Social and Humanistic Sciences from the University of Sciences and Arts of Chiapas. Professor of the Faculty of Social Sciences UNACH. PRODEP-SEP profile. Research lines: historical documentary heritage, gender.

Citation: Ana Berónica Palacios Gámaz, et.al. "Assessment on Professional Training and Labor Performance of Graduates of the Degree in Sociology". International Journal of Humanities Social Sciences and Education (IJHSSE), vol. 6, no.9, 2019, pp. 1-9. doi: http://dx.doi.org/10.20431/2349-0381.0609001.

Copyright: (c) 2019 Authors. This is an open-access article distributed under the terms of the Creative Commons Attribution License, which permits unrestricted use, distribution, and reproduction in any medium, provided the original author and source are credited. 